\title{
Vision and Requirements of Scenario-Driven Environmental Decision Support Systems Supporting Automation for End Users
}

\author{
Sascha Schlobinski ${ }^{1}$, Ralf Denzer ${ }^{2}$, Steven Frysinger ${ }^{2,3}$, \\ Reiner Güttler ${ }^{2}$, and Thorsten Hell ${ }^{1}$ \\ ${ }^{1}$ cismet GmbH, Altenkesseler Strasse 17, 66115 Saarbrücken \\ ${ }^{2}$ Environmental Informatics Group (EIG), Goebenstrasse 40, 66117 Saarbrücken, Germany \\ ${ }^{3}$ James Madison University, Harrisonburg, Virginia, USA 22807 \\ sascha.schlobinski@cismet.de
}

\begin{abstract}
This paper discusses the vision and requirements of a highly interactive workbench which supports decision makers using distributed resources including models as automated components of an integrated environmental decision support system. The concepts discussed are results of the SUDPLAN project, an EU FP7 project which aims at developing advanced tools for climate change adaptation for city planners and city managers. To this end, SUDPLAN incorporates access to climate change models and model results as an important common service. This paper provides an overview of SUDPLAN, with special emphasis on the highly interactive Scenario Management System. It also includes an overview of the user requirements derived through a user-centred design process engaging highly diverse user representatives of four pilot application cities.
\end{abstract}

Keywords: workflow automation; data infrastructures; visualization; climate change; environmental decision support system.

\section{Introduction}

The Sustainable Urban Development Planner for Climate Change Adaptation (SUDPLAN) is intended to help municipal decision makers and their scientific consultants consider the possible impacts of climate change as they make medium to long-term plans for development or modification of their cities [1]. In order to do this, they will need access to sophisticated climate modeling results pertaining to their region, which in turn requires downscaling of modeling results from global climate models [2].

A major contribution of SUDPLAN is to make such models and related data sets and services available to decision makers who would normally not have access to them, along with data and information describing their impact in the local context.

This is achieved through a flexible workbench framework that may be readily adapted to different regions and different decision problems. By taking a systematic approach, which has been inherited from the FP6 projects ORCHESTRA [3]) and SANY [4], SUDPLAN is compliant with existing infrastructures supporting the 
emerging Single Information Space in Europe for the Environment [5]. In addition, developing the requirements for SUDPLAN in close cooperation with four distinct pilot cities has made it possible to achieve a remarkable level of flexibility and adaptability.

\section{The SUDPLAN Vision}

The principal idea of the SUDPLAN project is to develop an easy-to-use web-based planning, prediction, and decision support tool. This is to be used in an urban context, based on a 'what-if' scenario execution environment, and is designed to help assure a population's health, safety, and quality of life as well as the sustainability of investments in utilities and infrastructures within the context of a changing climate.

SUDPLAN provides a new and visionary capacity to link existing environmental models, information and sensor infrastructures, spatial data infrastructures, and climatic scenario databases, providing visualisation of long-term forecasts of environmental factors for urban subsystems such as buildings, transportation, landscapes, and water management systems. Decision makers will be able to evaluate the risks of such phenomena as river flooding, storm water runoff, and elevated air pollution levels for existing or planned urban areas subject to a changing climate.

The planning of urban infrastructure is typically based on a statistical evaluation of historical data. Traditionally, for example, such data are used to quantify the maximum river runoff during a 100-year period, the most intense rainfall occurring within a similar period, or the risks associated with a concurrent air pollution event and heat wave. But the temperature increase, changes in precipitation and air pollution levels, and variation in storm patterns expected to occur during the coming decades may invalidate those historical analyses and necessitate new assessments based on forecasted climate scenarios. SUDPLAN will make it possible for city planners to include such analyses in a simple and cost-effective manner.

Sustainable cities will require an integrated planning approach. Using SUDPLAN, planners will be able to assess some of the most important environmental factors. Sustainability is approached during both present and predicted climate scenarios which are simulated by regional climate models derived through down scaling from global climate models. This means there will be modeling at the European scale, from which SUDPLAN services may be used to further downscale future climate variables to the urban scale, where they can be used as input to local models implemented over planned or existing urban areas and visualised using a variety of techniques [6].

SUDPLAN provides urban planners and decision makers with a web-based scenario management environment. This tool will allow them to manage scenarios, and to execute, visualise and compare them with each other and with real developments over 3-space and time, in order to carry out scenario-based prediction, damage assessment, planning, and training. SUDPLAN uses 3D/4D modeling, as well as simulation and visualisation coupled with existing resources, such as sensor networks, and provides ready access to integrated and high quality information regarding urban environmental factors for both current and future scenarios. SUDPLAN allows onthe-fly combination and production of forecasts from different types of models, sensors, and geospatial information in 2D and 3D (such as land use and topography). 


\section{The Scenario Management System Requirements}

Early in the development of the SUDPLAN vision it was recognized that different cities would be concerned with different decision problems requiring different analytical tools and data sets. In order to arrive at the specification of a platform flexible enough to suit many such application contexts, a variant of user-centered design [7] was employed.

In conventional user-centered design, representative users of a software application are engaged to help with the design process through a variety of needs assessment techniques in a process which is usually iterative. Carefully done, the ultimate design is then much more likely to suit the needs of the application's targeted users.

To apply this process to SUDPLAN - which is not a single application but a framework for applications - it was necessary to identify representative application contexts and then carry out the user-centred design process for each of them. Once this was accomplished the resulting application requirements could be compared in order to discern common elements and structural features.

Four pilot urban application contexts were chosen: Linz (Austria), Prague (Czech Republic), Stockholm (Sweden), and Wuppertal (Germany). Each of these pilots was interested in different decision problems, and each had somewhat different decision makers (and other users) who would be of interest.

\subsection{Needs Assessment}

The first step towards the requirements specification [8] included interviews with the people involved in the pilot applications, and assessment and documentation of other relevant aspects. The interviews were carried out with a strong focus on the following important goals:

- identifying the users involved in each pilot's decision process and their role (e.g. direct or indirect users of the system)

- discerning the decisions the pilot application must support

- learning what information and data (amount, representation, flow) will be required

- identifying visualisation and interaction needs

- discovering available subsystems.

The second step consisted of the identification of the tasks the user(s) of the SUDPLAN applications must be able to perform. The identified tasks were decomposed into a hierarchy of sub-tasks simple enough to enable identification of the resources (data and services) needed to perform the lowest level tasks. This step resulted in definitions of the pilots which served as the basis for plans that document the identified tasks and associated use-cases necessary for the analysis and extraction of functional requirements. The SUDPLAN platform requirements reflect these use-cases and tasks. In addition, SUDPLAN platform requirements are also derived from experience in other projects [9],[10], the literature, and general software engineering and interaction design practice. 


\subsection{User Requirements Derivation}

A key step in the specification of user requirements is the definition of the users. It was possible to develop a generalized definition of primary, secondary and tertiary users in a way which was generic across the application contexts of the four pilots.

SUDPLAN users are described in three basic categories:

- Analysts are those who will be using the SUDPLAN applications on a regular basis to carry out analyses in order to arrive at an environmental management decision. In some cases they may be the decision makers, and in some cases they may be supporting the decision makers. The precise nature of their tasks depends on the particular decision problem they are addressing (e.g. flood management, air quality control, etc.)

- Modellers are those people who develop, integrate, and/or configure mathematical models to be used within SUDPLAN applications.

- System Managers are those people who install and maintain SUDPLAN applications and carry out general system administration tasks.

Characterizing SUDPLAN pilot users in a generic way simplified the data gathering and generalization process, and facilitated derivation of requirements for a platform that could support these users in their various geographic and management contexts.

\subsection{User Requirements Overview}

User requirements were divided into four categories:

- Common user requirements

- Requirements of analysts

- Requirements of modellers

- Requirements of system managers

While the user requirements described here are important, individually they are not necessarily unique. But their integration into a single platform supporting families of environmental decision support systems is. Looking at the entire information processing chain for all involved stakeholders in a holistic way is the essential character of the SUDPLAN Scenario Management System.

\subsubsection{Common User Requirements}

Not surprisingly, the common user requirements (i.e. those shared by all three categories of user) included state-of-the-practice attention to usability and user-centered design. After all, SUDPLAN implementations will no doubt be complex, and therefore the user interfaces need to be as easy to use as possible. This is especially critical when it comes to users from specific disciplines interacting with interdisciplinary aspects of the modelled system. To the extent possible, users should not have to educate themselves outside of their disciplines in order to effectively use the system. Table 1 summarizes in more detail the common user requirements. 
Table 1. Common User Requirements Summary

\begin{tabular}{|c|c|c|}
\hline Category & Requirement & Rationale \\
\hline \multirow[t]{7}{*}{ Usability } & $\begin{array}{l}\text { User-centered } \\
\text { design }\end{array}$ & $\begin{array}{l}\text { Systematic user-centered design helps ensure that } \\
\text { the intended users are successful and improves } \\
\text { overall productivity. }\end{array}$ \\
\hline & User Errors & $\begin{array}{l}\text { Preventing or successfully mitigating user errors is } \\
\text { necessary to ensure a productive outcome of the } \\
\text { users' use of the system. }\end{array}$ \\
\hline & $\begin{array}{l}\text { Short-term } \\
\text { Memory }\end{array}$ & $\begin{array}{l}\text { Avoiding a reliance on the users' short-term } \\
\text { memory significantly increases productivity, } \\
\text { reduces error rates, and increases user satisfaction. }\end{array}$ \\
\hline & Contextual Help & $\begin{array}{l}\text { When users are expected to provide input to an } \\
\text { application they may need clarification or } \\
\text { explanation of the input that is expected of them. }\end{array}$ \\
\hline & Ease of Learning & $\begin{array}{l}\text { Users should be able to learn how to use the user } \\
\text { interface easily and to readily understand its } \\
\text { functionality. }\end{array}$ \\
\hline & Memorability & $\begin{array}{l}\text { Users should be able to readily remember how to } \\
\text { use the user interface. }\end{array}$ \\
\hline & Transparency & $\begin{array}{l}\text { Users should not need to have technical knowledge } \\
\text { outside of their domain. }\end{array}$ \\
\hline \multirow[t]{2}{*}{ Automation } & $\begin{array}{l}\text { Recurring Task } \\
\text { Automation }\end{array}$ & $\begin{array}{l}\text { There are tasks which must be performed } \\
\text { repeatedly. Allowing the users to automate such } \\
\text { tasks will greatly enhance ultimate productivity. }\end{array}$ \\
\hline & $\begin{array}{l}\text { Recurring Task } \\
\text { Configuration }\end{array}$ & $\begin{array}{l}\text { Recurring tasks will generally require } \\
\text { configuration of input data, parameters, and other } \\
\text { variables. }\end{array}$ \\
\hline \multirow[t]{4}{*}{ Profiling } & $\begin{array}{l}\text { Profiling of the } \\
\text { User Interface }\end{array}$ & $\begin{array}{l}\text { User interfaces generally allow configuration by } \\
\text { users to suit their needs or preferences. Keeping } \\
\text { these configurations in a profile prevents any given } \\
\text { user from having to reconfigure the application } \\
\text { each time they use it. }\end{array}$ \\
\hline & $\begin{array}{l}\text { Establishment of } \\
\text { User Groups }\end{array}$ & $\begin{array}{l}\text { Some aspects of the user interface configuration } \\
\text { may be associated with categories of users rather } \\
\text { than individual users. }\end{array}$ \\
\hline & $\begin{array}{l}\text { Profiling of } \\
\text { Automation Tasks }\end{array}$ & $\begin{array}{l}\text { Automatically recurring task configurations should } \\
\text { be stored in a profile to allow users to re-establish } \\
\text { similar task executions without having to } \\
\text { completely re-enter configuration information. }\end{array}$ \\
\hline & $\begin{array}{l}\text { Profiling of } \\
\text { Business } \\
\text { Processes }\end{array}$ & $\begin{array}{l}\text { Applications will often require combinations of } \\
\text { information and services requested from diverse } \\
\text { sources, and these request transactions will need to } \\
\text { be configured. Saving of request transaction profiles } \\
\text { will help users to streamline their analyses by } \\
\text { avoiding extensive reconfiguration. }\end{array}$ \\
\hline
\end{tabular}




\subsubsection{Requirements of Analysts}

Over and above these common requirements, which apply to all user categories, one particular category of user - analysts - has very specific requirements. One area of significance to analysts is the management of the tremendous amount of information which must be brought to bear in their analyses. Finding, validating, and managing input data, along with appropriate management and display of results are key to this user's function.

Besides this, the nature of the human decision making process, often a 'what if' process, requires that the system be highly interactive, allowing them to manipulate parameters and see corresponding changes in the results as soon as possible thereafter. This necessitates technical approaches such as caching and preloading to facilitate manipulation of large data sets and/or model results.

In addition, analysts need to be able to control the modelling and analysis process itself. This implies the ability to manage the models involved in a simulation scenario, and to have relatively convenient access to models and modelling results regardless of whether the models execute quickly or take a great deal of time to complete. Various techniques (such as asynchronous and pre-calculated model execution) are required to support this flexibility. The ability to save and share model execution scenarios is a natural extension of this.

Finally, and of at least as much importance, is the need to display, report, and publish the results of analyses. Decision-making requires cognitive access to the information that is relevant to the decision. This includes visualization of data to the analyst, as well as reporting of data to other stakeholders and, ultimately, publishing of results to a larger community, possibly to include the general public. Table 2 summarizes in more detail the requirements of analysts.

Table 2. Analyst Requirements Summary

\begin{tabular}{|l|l|l|}
\hline \multicolumn{1}{|c|}{ Category } & \multicolumn{1}{|c|}{ Requirement } & \multicolumn{1}{c|}{ Rationale } \\
\hline $\begin{array}{l}\text { Information } \\
\text { Management }\end{array}$ & $\begin{array}{l}\text { Information } \\
\text { Source } \\
\text { Management }\end{array}$ & $\begin{array}{l}\text { An information-intensive application must } \\
\text { facilitate the finding, storing, and utilization of } \\
\text { information within the application in order to } \\
\text { support user success and satisfaction. }\end{array}$ \\
\cline { 2 - 3 } & $\begin{array}{l}\text { Management of } \\
\text { Related } \\
\text { Knowledge }\end{array}$ & $\begin{array}{l}\text { Besides actual input data, there may be other } \\
\text { information valuable to the analyst, and this } \\
\text { information needs to be readily accessible to the } \\
\text { users. }\end{array}$ \\
\cline { 2 - 3 } & $\begin{array}{l}\text { Distributed } \\
\text { Information } \\
\text { Sources }\end{array}$ & $\begin{array}{l}\text { Applications will often rely on data from multiple } \\
\text { external sources. }\end{array}$ \\
\cline { 2 - 3 } & $\begin{array}{l}\text { Output Data } \\
\text { Management }\end{array}$ & $\begin{array}{l}\text { Applications will produce results in a wide } \\
\text { variety of forms. These data need to be easily } \\
\text { accessible to and manipulated by the analysts. }\end{array}$ \\
\hline
\end{tabular}


Table 2. (continued)

\begin{tabular}{|c|c|c|}
\hline & $\begin{array}{l}\text { Result Processing } \\
\text { Management }\end{array}$ & $\begin{array}{l}\text { Given the complexity of applications, output data } \\
\text { resulting from primary analytical techniques may } \\
\text { need to be post-processed by the user, and system } \\
\text { support for these activities is necessary. }\end{array}$ \\
\hline & $\begin{array}{l}\text { Information } \\
\text { Product } \\
\text { Management }\end{array}$ & $\begin{array}{l}\text { Information products produced by analysts must } \\
\text { be stored and managed in an organized and } \\
\text { accessible fashion. }\end{array}$ \\
\hline & $\begin{array}{l}\text { Coordinate } \\
\text { Conversion }\end{array}$ & $\begin{array}{l}\text { Information products produced throughout the } \\
\text { platform must be easily convertible to other } \\
\text { spatial reference systems. }\end{array}$ \\
\hline & Tracing & $\begin{array}{l}\text { The system should support the tracing of user and } \\
\text { system component interactions. }\end{array}$ \\
\hline \multirow[t]{4}{*}{ Interactivity } & $\begin{array}{l}\text { General } \\
\text { Interactivity } \\
\text { Requirements }\end{array}$ & $\begin{array}{l}\text { The system shall support analysts by including } \\
\text { design features which facilitate manipulation of } \\
\text { elements of the modelled system (e.g. parameters, } \\
\text { variables, input data). }\end{array}$ \\
\hline & Responsiveness & $\begin{array}{l}\text { When the analyst has manipulated an input to the } \\
\text { modelling system, the system needs to provide an } \\
\text { immediate response to this change in situations } \\
\text { where that makes sense and is possible. }\end{array}$ \\
\hline & Local Data Copy & $\begin{array}{l}\text { Pre-fetching and caching data locally can greatly } \\
\text { improve the users' experience of interactive } \\
\text { exploration of the data. }\end{array}$ \\
\hline & $\begin{array}{l}\text { Differential Data } \\
\text { Download }\end{array}$ & $\begin{array}{l}\text { Many data sources contain data that only } \\
\text { infrequently change. Fetching of "changes only" } \\
\text { in combination with pre-fetching and caching can } \\
\text { therefore greatly improve the system } \\
\text { responsiveness. }\end{array}$ \\
\hline \multirow[t]{4}{*}{$\begin{array}{l}\text { Model } \\
\text { Management }\end{array}$} & $\begin{array}{l}\text { Initial and } \\
\text { Boundary } \\
\text { Conditions }\end{array}$ & $\begin{array}{l}\text { Mathematical models require parameters } \\
\text { describing initial and boundary conditions of the } \\
\text { model. It is essential that users be assisted where } \\
\text { possible in choosing and establishing those } \\
\text { conditions. }\end{array}$ \\
\hline & Condition Sets & $\begin{array}{l}\text { Particular combinations of initial and boundary } \\
\text { condition parameters can be stored as a set, and } \\
\text { then reused in subsequent model runs. }\end{array}$ \\
\hline & $\begin{array}{l}\text { Synchronous Model } \\
\text { Execution }\end{array}$ & $\begin{array}{l}\text { Models which generally run to completion } \\
\text { quickly can be run by users who choose to wait } \\
\text { for completion. }\end{array}$ \\
\hline & $\begin{array}{l}\text { Asynchronous Model } \\
\text { Execution }\end{array}$ & $\begin{array}{l}\text { Since some models will take considerable time to } \\
\text { complete, users may choose to run these models } \\
\text { asynchronously. }\end{array}$ \\
\hline
\end{tabular}


Table 2. (continued)

\begin{tabular}{|c|c|c|}
\hline & $\begin{array}{l}\text { Model Set } \\
\text { Execution }\end{array}$ & $\begin{array}{l}\text { Extending the concept of asynchronous model } \\
\text { execution, users can run multiple instances of the } \\
\text { same model combination with varying sets of } \\
\text { parameters, producing a "family" of results. }\end{array}$ \\
\hline & $\begin{array}{l}\text { Pre-calculated } \\
\text { Model Execution }\end{array}$ & $\begin{array}{l}\text { For computationally intensive models limiting the } \\
\text { number of times the model has to be executed, } \\
\text { and using stored results from previous runs, can } \\
\text { help model combinations which use these results } \\
\text { to execute in a timely fashion, and can also reduce } \\
\text { redundant use of computational resources. }\end{array}$ \\
\hline & Model Status & $\begin{array}{l}\text { Computationally intensive models can take } \\
\text { considerable time to execute, and during their } \\
\text { execution analysts will need to be able to check } \\
\text { their status. }\end{array}$ \\
\hline \multirow[t]{2}{*}{ Scenarios } & $\begin{array}{l}\text { Establishing } \\
\text { Scenarios }\end{array}$ & $\begin{array}{l}\text { Users need to be able to specify the values for } \\
\text { parameters within a scenario (including initial and } \\
\text { boundary conditions), as well as the particular } \\
\text { models to be included for each scenario. }\end{array}$ \\
\hline & $\begin{array}{l}\text { Scenario } \\
\text { Management }\end{array}$ & $\begin{array}{l}\text { As users define scenarios, they will need to be } \\
\text { able to manage them. }\end{array}$ \\
\hline \multirow[t]{6}{*}{ Visualisation } & $\begin{array}{l}\text { 3D/4D } \\
\text { Visualisation }\end{array}$ & $\begin{array}{l}\text { Analysts need to carry out exploratory data } \\
\text { analysis on 3- and 4-dimensional data sets, and } \\
\text { therefore need visualization support for these } \\
\text { data. }\end{array}$ \\
\hline & $\begin{array}{l}\text { Spatial } \\
\text { Visualisation }\end{array}$ & $\begin{array}{l}\text { Environmental data are very often spatial in } \\
\text { nature, and therefore require geo-spatial } \\
\text { visualization techniques. }\end{array}$ \\
\hline & $\begin{array}{l}\text { Temporal } \\
\text { Visualisation }\end{array}$ & $\begin{array}{l}\text { Environmental phenomena are dynamic in nature, } \\
\text { and therefore often require the use of } \\
\text { visualization techniques representation variation } \\
\text { of one or more variables as a function of time. }\end{array}$ \\
\hline & $\begin{array}{l}\text { Spatio-temporal } \\
\text { Visualisation }\end{array}$ & $\begin{array}{l}\text { More complex environmental data sets vary in } \\
\text { both time and space. }\end{array}$ \\
\hline & $\begin{array}{l}\text { Visualisation of a } \\
\text { Model Run Result }\end{array}$ & $\begin{array}{l}\text { Many model runs will generate spatial and/or } \\
\text { temporal data which need to be visualized to be } \\
\text { interpreted by the analyst. }\end{array}$ \\
\hline & $\begin{array}{l}\text { Comparison of } \\
\text { Model Run } \\
\text { Results }\end{array}$ & $\begin{array}{l}\text { Analysis of the results from multiple comparable } \\
\text { model runs (such as under different scenarios) } \\
\text { requires the ability to simultaneously represent } \\
\text { model results visually. }\end{array}$ \\
\hline
\end{tabular}


Table 2. (continued)

\begin{tabular}{|c|c|c|}
\hline \multirow[t]{2}{*}{$\begin{array}{l}\text { Result } \\
\text { Documentation and } \\
\text { Annotation }\end{array}$} & $\begin{array}{l}\text { Documentation of } \\
\text { a Model Run }\end{array}$ & $\begin{array}{l}\text { The results of each model run needs to be } \\
\text { annotated before being stored in order to facilitate } \\
\text { search and recovery. }\end{array}$ \\
\hline & $\begin{array}{l}\text { Documentation of } \\
\text { Scenario Set } \\
\text { Execution }\end{array}$ & $\begin{array}{l}\text { In addition to storing annotations about individual } \\
\text { model runs, analysts will need to annotate } \\
\text { scenario sets as well. }\end{array}$ \\
\hline \multirow[t]{3}{*}{$\begin{array}{l}\text { Information } \\
\text { Products }\end{array}$} & $\begin{array}{l}\text { Creation of } \\
\text { Information } \\
\text { Products }\end{array}$ & $\begin{array}{l}\text { The value of an analysis can be greatly enhanced } \\
\text { by producing information products which are also } \\
\text { accessible to other stakeholders. Analysts will } \\
\text { require system support to help them generate such } \\
\text { information products. }\end{array}$ \\
\hline & Report Generation & $\begin{array}{l}\text { Basic reports making the results of scenario } \\
\text { execution accessible to non-analysts are necessary } \\
\text { in order to communicate the results to the other } \\
\text { stakeholders. }\end{array}$ \\
\hline & Export & $\begin{array}{l}\text { In order to support the generation of information } \\
\text { products beyond basic reports, the analyst will } \\
\text { need to be able to export artefacts (such as model } \\
\text { execution results or visualized data) to other } \\
\text { formats for use of external tools. }\end{array}$ \\
\hline \multirow[t]{5}{*}{ Sharing } & $\begin{array}{l}\text { Information } \\
\text { Sharing }\end{array}$ & $\begin{array}{l}\text { Information regarding an application, including } \\
\text { but not limited to input data, should be readily } \\
\text { shared between consenting analysts to facilitate } \\
\text { collaboration and efficiency. }\end{array}$ \\
\hline & Result Sharing & $\begin{array}{l}\text { The results of model and scenario set execution } \\
\text { can be useful for analysts working on the same or } \\
\text { related applications, and should be readily shared } \\
\text { along with their documentation annotations. }\end{array}$ \\
\hline & $\begin{array}{l}\text { Information } \\
\text { Product Sharing }\end{array}$ & $\begin{array}{l}\text { Multiple analysts might be producing similar } \\
\text { information products to communicate their } \\
\text { results. Sharing of these products encourages } \\
\text { efficiency and consistency. }\end{array}$ \\
\hline & $\begin{array}{l}\text { Automation } \\
\text { Sharing }\end{array}$ & $\begin{array}{l}\text { The configuration of automation tasks can } \\
\text { become complex for some complicated modelling } \\
\text { systems. Sharing these configurations for re-use } \\
\text { brings increased efficiency and quality control. }\end{array}$ \\
\hline & $\begin{array}{l}\text { Annotation } \\
\text { Sharing }\end{array}$ & $\begin{array}{l}\text { Sharing of annotations among analysts working } \\
\text { on the same data sets can increase their efficiency } \\
\text { and support additional quality control. }\end{array}$ \\
\hline
\end{tabular}


Table 2. (continued)

\begin{tabular}{|l|l|l|}
\hline Publishing & $\begin{array}{l}\text { Information } \\
\text { Publishing }\end{array}$ & $\begin{array}{l}\text { Analysts may wish to make their data and other } \\
\text { information available to other web-based services, } \\
\text { and therefore need a mechanism for publishing } \\
\text { this information to the Internet. }\end{array}$ \\
\cline { 2 - 3 } & Web Publishing & $\begin{array}{l}\text { Results such as visualizations and information } \\
\text { products, may be shared as web content in order } \\
\text { to enhance the value added by the analyses. }\end{array}$ \\
\cline { 2 - 3 } & $\begin{array}{l}\text { Web Publishing } \\
\text { Standards }\end{array}$ & $\begin{array}{l}\text { Adherence to standards will increase the } \\
\text { availability of information to the wider } \\
\text { community. }\end{array}$ \\
\hline
\end{tabular}

\subsubsection{Requirements of Modellers}

Modellers have somewhat narrower requirements, focused as they are on the finetuning and integration of models into the decision support system framework. Since they are generally somewhat more specialized than the analysts, their needs are also more specific. But because they are involved with the integration of models (not all of

Table 3. Modeller Requirements Summary

\begin{tabular}{|c|c|c|}
\hline Category & Requirement & Rationale \\
\hline \multirow[t]{2}{*}{$\begin{array}{l}\text { Model } \\
\text { Management }\end{array}$} & Model Integration & $\begin{array}{l}\text { Integrating models into an application, possibly } \\
\text { with other models, means that the modeller needs } \\
\text { to be able to specify the role of the model(s) } \\
\text { within the application and to make the necessary } \\
\text { connections between the model(s) and other } \\
\text { components of the application. }\end{array}$ \\
\hline & Model Configuration & $\begin{array}{l}\text { Modellers need to be able to configure models by } \\
\text { specifying those data which are necessary for the } \\
\text { model but which will not be under the control of } \\
\text { the analyst. }\end{array}$ \\
\hline \multirow[t]{3}{*}{$\begin{array}{l}\text { Model Calibration } \\
\text { and Validation }\end{array}$} & Model Calibration & $\begin{array}{l}\text { If an application provides access to sufficient } \\
\text { measurement data, it may be desirable to } \\
\text { calibrate the model(s) used within the application } \\
\text { to those data. }\end{array}$ \\
\hline & Model Validation & $\begin{array}{l}\text { If an application has access to sufficient } \\
\text { measurement data, using these data to validate } \\
\text { the model(s) can increase confidence in the } \\
\text { results of the model(s) within the context of the } \\
\text { application. }\end{array}$ \\
\hline & Model Versions & $\begin{array}{l}\text { If different versions of a model are available it is } \\
\text { necessary for these versions to be managed in } \\
\text { such a way that analysts can distinguish their } \\
\text { features and employ the correct version for their } \\
\text { needs. }\end{array}$ \\
\hline
\end{tabular}


which are necessarily within their specialty) they require particular help in the areas of assumption harmonization and calibration/validation of integrated models [11]. They must also be supported in coping with a range of versions of particular models, and require assistance in distinguishing the nature of their differences. Table 3 summarizes in more detail the requirements of modellers.

\subsubsection{Requirements of System Managers}

Finally, system managers have particular requirements. These include provision for user identification and authorization, and extend to the representation of authorized users to external systems with their own authentication requirements. The system manager may be responsible for integration of data, sensor data, services, and models into a platform configuration supporting the analysts, and will therefore require support for all of these tasks. Table 4 summarizes in more detail the requirements of system managers.

Table 4. System Manager Requirements Summary

\begin{tabular}{|l|l|l|}
\hline \multicolumn{1}{|c|}{ Category } & \multicolumn{1}{|c|}{ Requirement } & \multicolumn{1}{c|}{ Rationale } \\
\hline $\begin{array}{l}\text { Platform } \\
\text { Management }\end{array}$ & User Management & $\begin{array}{l}\text { In order to manage access to an application the } \\
\text { system manager needs to be able to specify users } \\
\text { and groups of users to the system. }\end{array}$ \\
\cline { 2 - 3 } Security and Rights & Management & $\begin{array}{l}\text { System managers need to be able to specify which } \\
\text { users are authorized to have what level of access } \\
\text { to which parts of the application. }\end{array}$ \\
\hline Integration & $\begin{array}{l}\text { Data Source } \\
\text { Integration }\end{array}$ & $\begin{array}{l}\text { An application may use data from a variety of } \\
\text { sources. The system manager needs to be able to } \\
\text { integrate these data sources into the application } \\
\text { for the system analyst. }\end{array}$ \\
\cline { 2 - 3 } & $\begin{array}{l}\text { Sensor Service } \\
\text { Integration }\end{array}$ & $\begin{array}{l}\text { Applications may use sensor services that are } \\
\text { either local to the application or that are } \\
\text { distributed and accessible via the web. }\end{array}$ \\
\cline { 2 - 3 } & Service Integration & $\begin{array}{l}\text { Applications may use other non-modelling } \\
\text { services that are either local to the application or } \\
\text { that are distributed and accessible via the web. }\end{array}$ \\
\hline
\end{tabular}

\section{Architecture and Status of Implementation}

An overview of the overall architecture of SUDPLAN has been described elsewhere [12]. The first version of the system has been finalised during the first project year, and will be extended and upgraded during the next 2 years.

The Scenario Management System itself is based on the cids geospatial application framework of cismet GmbH [13]. This framework has been developed over more than 10 years [14] and has applications in a number of environmental management and planning applications. 
SUDPLAN provides a contemporary example of a family of decision support systems which, though each sibling has uniquely individual needs, offers an economy of resemblance that allows expeditious development. The SUDPLAN pilot applications' disparate contexts and needs might challenge decision support system developers not approaching the problem as systematically as SUDPLAN has done. Yet in this case, these pilot applications yielded to a framework which played on the structural similarities of these applications, while acknowledging their differences.

These interim observations and results must finally, of course, be evaluated as the pilot systems are released to their intended decision makers. Such evaluation is still ahead. It will also be interesting to ascertain, if the opportunity arises, how much of the success of SUDPLAN depends on certain similarities between the pilots, i.e. that they were all urban contexts, and that the predominant issue was climate change. Experimental application of the SUDPLAN framework to other application contexts will go a long way toward answering this question.

\section{Acknowledgements}

SUDPLAN is a Collaborative Project (contract number 247708) co-funded by the Information Society and Media DG of the European Commission within the RTD activities of the Thematic Priority Information Society Technologies.

\section{References}

Denzer, R., Schlobinski, S., Gidhagen, L.: A Decision Support System for Urban Climate Change Adaptation. In: Proceedings of the 44th Hawaii International Conference on System Sciences (HICSS-44), CDROM. IEEE Computer Society, Los Alamitos (2011)

Gidhagen, L., Denzer, R., Schlobinski, S., Michel, F., Kutschera, P., Havlik, D.: Sustainable Urban Development Planner for Climate Change Adaptation (SUDPLAN). In: Proceedings of ENVIP 2010 workshop at EnviroInfo2010, "Environmental Information Systems and Services - Infrastructures and Platforms, Bonn, October 6-8. CEUR-WS, vol. 679 (2010) ISSN 1613-0073, urn:nbn:de:0074-679-9

Usländer, T. (ed.): Reference Model for the ORCHESTRA Architecture (RM-OA Version 2.1), OGC Best Practices Document, Open Geospatial Consortium (2007),

http: / /portal .opengeospatial.org/files/?artifact_id=23286

Douglas, J., Usländer, T., Schimak, G., Esteban, J.F., Denzer, R.: An Open Distributed Architecture for Sensor Networks for Risk Management. Journal Sensors 8, 1755-1773 (2008)

SEIS EC: Towards a Shared Environmental Information System (SEIS) (2008), http: / / www . eurlex . europa . eu/LexUriServ/LexUri.Serv. do?uri=COM: $2008: 0046:$ FIN : EN : PDF

Gidhagen, L., Denzer, R., Schlobinski, S., Michel, F., Kutschera, P., Havlik, D.: Sustainable Urban Development Planner for Climate Change Adaptation (SUDPLAN). In: Proceedings of ENVIP 2010 Workshop at EnviroInfo2010, "Environmental Information Systems and Ser-vices - Infrastructures and Platforms, Bonn, October 6-8. CEUR-WS, vol. 679 (2010) ISSN 1613-0073, urn:nbn:de:0074-679-9

Preece, Rogers, Sharp: Interaction Design: Beyond Human-Computer Interaction, 2nd edn. Wiley, Chichester (2007) 
SUDPLAN: Sustainable Urban Development Planner for Climate Change Adaptation - Requirements Specification (June 30, 2010), A public version will be available in 2011 at http: //www.smhi.se/sudplan/Results

Usländer, T., Denzer, R.: Requirements and Open Architecture of Environmental Risk Management Information Systems. In: van der Walle, B. (ed.) Information Systems for Emergency Management, pp. 344-368. M. E. Sharpe Publishers (2010) ISBN 978-0-7656-2134-4

Havlik, D.: SANY Final Activity Report (D1.1.5.1 Publishable Final Activity Report) (2010), http: / / sany-ip.eu/filemanager/active?fid=320

Frysinger, S.P.: Integrative Environmental Modeling. In: Clarke, K.C., Parks, B.E., Crane, M.P. (eds.) Geographic Information Systems and Environmental Modeling. Prentice Hall, Englewood Cliffs (2002)

Denzer, R., Schlobinski, S., Gidhagen, L.: A Decision Support System for Urban Climate Change Adaptation. In: Proceedings of the 44th Hawaii International Conference on System Sciences (HICSS-44), CDROM. IEEE Computer Society, Los Alamitos (2011)

Schlobinski, S., Hell, T., Denzer, R., Güttler, R.: Ein Werkzeug für die Entwicklung integrierter Fachanwendungen im Umfeld verteilter Daten- und Service-Infrastrukturen. In: Proceedings AGIT Conference, Salzburg (in press, 2011)

Güttler, R., Denzer, R., Houy, P.: An EIS Called WuNDa, Environmental Software Systems. Environmental Information and Decision Support, vol. 3, pp. 114-121. Kluwer Academic Publishers, Dordrecht (2000) 